\title{
Materials designing of metal borohydrides: Viewpoints from thermodynamical stabilities
}

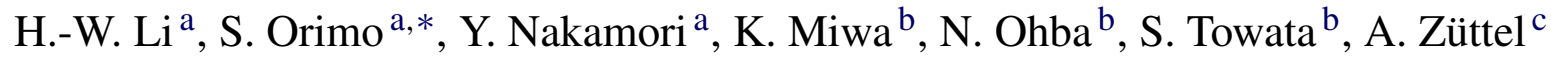 \\ ${ }^{a}$ Institute for Materials Research, Tohoku University, 2-1-1 Katahira, Aoba-Ku, Sendai 980-8577, Japan \\ ${ }^{\mathrm{b}}$ Toyota Central R\&D Labs., Inc., Nagakute, Aichi 480-1192, Japan \\ ${ }^{\mathrm{c}}$ Physics Department, University of Fribourg, Pérolles, CH-1700, Fribourg, Switzerland
}

\begin{abstract}
Double-cation borohydrides $\mathrm{MLi}_{m-n}\left(\mathrm{BH}_{4}\right)_{m}(\mathrm{M}=\mathrm{Zn}, n=2 ; \mathrm{M}=\mathrm{Al}, n=3 ; \mathrm{M}=\mathrm{Zr}, n=4 ; n \leq m)$ were expected to be synthesized and their thermodynamical stabilities were also examined experimentally. The samples with the compositions of $\left.\mathrm{ZnLi}_{(\mathrm{BH}}\right)_{3}$ and $\mathrm{AlLi}\left(\mathrm{BH}_{4}\right)_{4}$ disproportionate into $\mathrm{Zn}\left(\mathrm{BH}_{4}\right)_{2}-\left(\right.$ or $\left.\mathrm{Al}\left(\mathrm{BH}_{4}\right)_{3}{ }^{-}\right)$and $\mathrm{LiBH}_{4}$-based phases upon heating, respectively. However, no disproportionation reaction is observed in $\mathrm{ZrLi}_{m-4}\left(\mathrm{BH}_{4}\right)_{m}\left(m=5\right.$ and 6). It should be emphasized that hydrogen desorption temperature $T_{\mathrm{d}}$ of $\mathrm{ZrLi}_{m-4}\left(\mathrm{BH}_{4}\right)_{m}$ continuously increases from 440 to $650 \mathrm{~K}$ as the composition $m$ increases from 4 to 6 , and approaches to $740 \mathrm{~K}\left(T_{\mathrm{d}}\right.$ of $\left.\mathrm{LiBH}_{4}\right)$. The experimental results indicate that the combination of appropriate cations is an effective method to adjust the thermodynamical stabilities of metal borohydrides, similar to the conventional "alloying" method for hydrogen storage alloys.
\end{abstract}

Keywords: Hydrogen absorbing materials; Mechanical alloying; Thermodynamic properties; Thermal analysis

\section{Introduction}

Metal borohydrides $\left(\mathrm{M}\left(\mathrm{BH}_{4}\right)_{n}\right)$, such as $\mathrm{LiBH}_{4}$ and $\operatorname{Mg}\left(\mathrm{BH}_{4}\right)_{2}$ [1-19] have been attracting great interest as one of the potential candidates of advanced hydrogen storage materials, because of their high gravimetric hydrogen densities.

Recently, we have systematically investigated the thermodynamical stabilities of $\mathrm{M}\left(\mathrm{BH}_{4}\right)_{n}(\mathrm{M}=\mathrm{Li}, \mathrm{Na}, \mathrm{K}, \mathrm{Cu}, \mathrm{Mg}, \mathrm{Zn}, \mathrm{Sc}$, $\mathrm{Zr}$ and $\mathrm{Hf} ; n=1-4$ ) with a single cation by both first-principles studies and thermal desorption measurements [16]. The firstprinciples calculations indicated that charge transfer from $\mathrm{M}^{n+}$ to $\left[\mathrm{BH}_{4}\right]^{-}$is a key factor for the stability of $\mathrm{M}\left(\mathrm{BH}_{4}\right)_{n}[5,8,16]$ and also there exists a linear relationship between the calculated formation enthalpy $\Delta H$ of $\mathrm{M}\left(\mathrm{BH}_{4}\right)_{n}$ and the Pauling electronegativity $\chi_{\mathrm{P}}$ of $\mathrm{M}$ [16]. Experimentally, the thermal desorption temperature $T_{\mathrm{d}}$ of $\mathrm{M}\left(\mathrm{BH}_{4}\right)_{n}$ examined by gas chromatography was also closely correlated with $\chi_{\mathrm{P}}[16,17]$, as shown in Fig. 1. That is, $T_{\mathrm{d}}$ (closed circles) decreases with increasing the value

\footnotetext{
* Corresponding author. Tel.: +81 22215 2093; fax: +81 222152091 .

E-mail address: orimo@imr.tohoku.ac.jp (S. Orimo).
}

of $\chi_{\mathrm{P}}$. Therefore, the value of $\chi_{\mathrm{P}}$ of $\mathrm{M}$ is concluded to be an important indicator for estimating the thermodynamical stability of $\mathrm{M}\left(\mathrm{BH}_{4}\right)_{n}$, i.e. $T_{\mathrm{d}}$ of $\mathrm{M}\left(\mathrm{BH}_{4}\right)_{n}$ might be roughly adjusted by selecting $\mathrm{M}$ with the appropriate value of $\chi_{\mathrm{P}}$.

However, in the case of $\mathrm{M}\left(\mathrm{BH}_{4}\right)_{n}$ with a single cation $\mathrm{M}^{n+}$, precise adjustment of $T_{\mathrm{d}}$ might be difficult due to the inherent and discrete value of $\chi_{\mathrm{P}}$ for each metal. Thus, development of $\mathrm{MM}^{\prime}\left(\mathrm{BH}_{4}\right)_{n}$ with double-cation (or multi-cation) is expected to be quite useful to precisely adjust $T_{\mathrm{d}}$ for hydrogen storage applications [20]. This proposition is similar to the conventional "alloying" method for hydrogen storage alloys [21,22].

In the present study, we select some metals with different $\chi_{\mathrm{P}}$, whose basic information is summarized in Table 1. Among them, borohydrides composed of metals with larger $\chi_{\mathrm{P}}$, such as $\mathrm{Zn}\left(\chi_{\mathrm{P}}=1.6\right), \mathrm{Al}\left(\chi_{\mathrm{P}}=1.5\right)$ and $\mathrm{Zr}\left(\chi_{\mathrm{P}}=1.4\right)$, are reported to have lower $T_{\mathrm{d}}$, i.e. 398 [17,18], 334 [19] and $440 \mathrm{~K}$ [17], respectively. However, $\mathrm{Zn}\left(\mathrm{BH}_{4}\right)_{2}$ and $\mathrm{Al}\left(\mathrm{BH}_{4}\right)_{3}$ are so unstable that diborane as an impurity gas is released along with hydrogen desorption on heating [18,19]; while $\mathrm{Zr}\left(\mathrm{BH}_{4}\right)_{4}$ evaporates easily due to its low melting point. On the other hand, $\mathrm{LiBH}_{4}$ with the smaller $\chi_{\mathrm{P}}$ of $\mathrm{Li}$ is so stable that its $T_{\mathrm{d}}$ is approximately as high as $740 \mathrm{~K}$. Therefore, their thermal stabilities are expected to be 


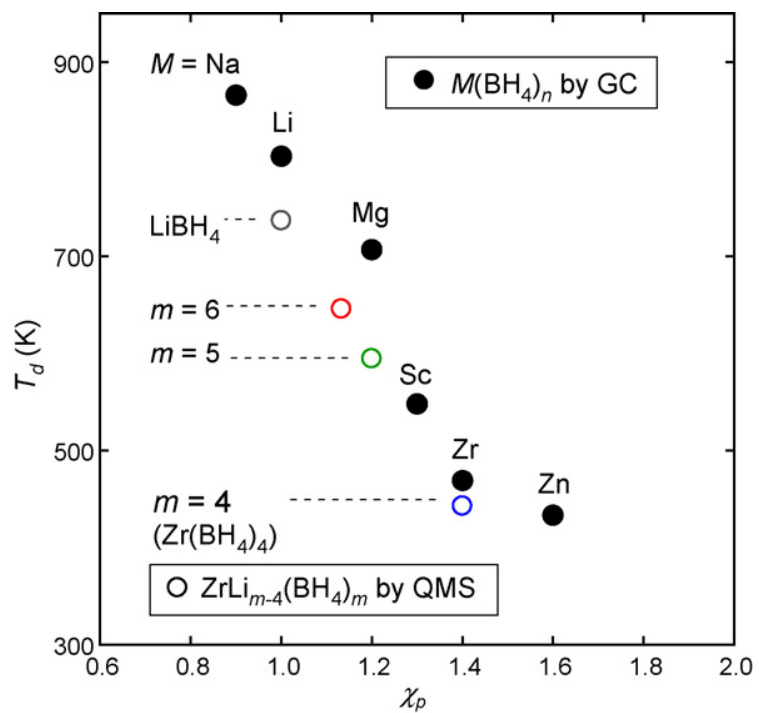

Fig. 1. Thermal desorption temperature $T_{\mathrm{d}}$ (main peak) as a function of the Pauling electronegativity $\chi_{\mathrm{P}}$. Closed and open circles indicate the series of single-cation borohydrides $\mathrm{M}\left(\mathrm{BH}_{4}\right)_{n}(\mathrm{M}=\mathrm{Li}, \mathrm{Na}, \mathrm{Mg}, \mathrm{Sc}, \mathrm{Zr}, \mathrm{Zn} ; n=1-4)$ and double-cation ones $\mathrm{ZrLi}_{m-4}\left(\mathrm{BH}_{4}\right)_{m}(m=4-6)$, examined by gas chromatography and quadrupole mass spectroscopy, respectively. There is a difference between $T_{\mathrm{d}}$ determined by gas chromatography and by quadrupole mass spectroscopy, owing to a longer distance between the detector and sample and also to a lower gas flow rate in gas chromatography.

adjusted for hydrogen storage application by the combination of two cations, i.e. the double-cation borohydrides $\mathrm{MLi}_{m-n}\left(\mathrm{BH}_{4}\right)_{m}$ $(\mathrm{M}=\mathrm{Zn}, n=2 ; \mathrm{M}=\mathrm{Al}, n=3 ; \mathrm{M}=\mathrm{Zr}, n=4 ; n \leq m)$ [23], which are expected to be synthesized according to the following reaction:

$\mathrm{MCl}_{n}+m \mathrm{LiBH}_{4} \rightarrow \mathrm{MLi}_{m-n}\left(\mathrm{BH}_{4}\right)_{m}+n \mathrm{LiCl}$

The enthalpy changes of this reaction are calculated by using the reported values of the formation enthalpies for $\mathrm{MCl}_{n}$ [24] and $\mathrm{LiBH}_{4}$ [5] and the values for $\mathrm{MLi}_{m-n}\left(\mathrm{BH}_{4}\right)_{m}$ formed from M, $\mathrm{Li}, \mathrm{B}$ and $\mathrm{H}_{2}$, can be theoretically predicted by the equation; $248.7 \chi_{\mathrm{P}}-390.8\left(\chi_{\mathrm{P}}\right.$ is the averaged values of Pauling electronegativity described later) [16]. Any of the samples have their

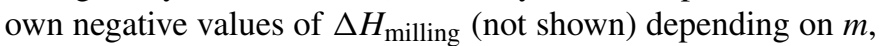
indicating that the reactions can occur "exothermically" in the wide composition ranges of $m$ [20].

The purpose is to clarify whether the method to precisely adjust the hydrogen desorption temperature of metal borohydrides by the combination of two metals with different electronegativities is feasible or not. This study provides the

Table 1

Basic information of $\mathrm{M}$ and their borohydrides $\mathrm{M}\left(\mathrm{BH}_{4}\right)_{n}$

\begin{tabular}{lllll}
\hline & $\mathrm{M}$ & & & \\
\cline { 2 - 5 } & $\mathrm{Zn}$ & $\mathrm{Al}$ & $\mathrm{Zr}$ & $\mathrm{Li}$ \\
\hline$\chi_{\mathrm{P}}(\mathrm{K})$ of $\mathrm{M}\left(\mathrm{BH}_{4}\right)_{n}$ & $398^{\mathrm{a}}[17,18]$ & $334^{\mathrm{a}}[19]$ & $440^{\mathrm{b}}[17]$ & 740 \\
\hline$T_{\mathrm{d}}(19)$ & & & \\
\hline
\end{tabular}

${ }^{\text {a }}$ Diborane as a impurity gas is released along with hydrogen desorption on heating.

${ }^{\text {b }} \mathrm{Zr}\left(\mathrm{BH}_{4}\right)_{4}$ has low melting point, i.e. $301.7 \mathrm{~K}$. fundamental information on the development of new metal borohydrides with appropriate thermal desorption temperature for hydrogen storage applications.

\section{Experimental}

Anhydrous $\mathrm{MCl}_{n}(\mathrm{M}=\mathrm{Zn}, \mathrm{Al}$ and $\mathrm{Zr})$ with 99.9-99.999\% purities and $\mathrm{LiBH}_{4}$ with $95 \%$ purity, were purchased from Aldrich Co. Ltd. The mixture of $\mathrm{MCl}_{n}$ and $m \mathrm{LiBH}_{4}$ was premixed manually using an agate mortar and pestle and then mechanically milled by planetary ball milling (Fritsch P-7) in $0.1 \mathrm{MPa}$ Ar for $5 \mathrm{~h}$ to synthesize $\mathrm{MLi}_{m-n}\left(\mathrm{BH}_{4}\right)_{m}(\mathrm{M}=\mathrm{Zn}, n=2 ; \mathrm{M}=\mathrm{Al}, n=3 ; \mathrm{M}=\mathrm{Zr}$, $n=4 ; n \leq m)$ according to equation (1). The milling process was paused every $15 \mathrm{~min}$ to avoid an increase in temperature of the sample. The samples, thus prepared were subjected to powder X-ray diffraction measurement $(\mathrm{Cu} \mathrm{K} \alpha$ radiation), Raman spectroscopy (532 nm-laser with back scattering geometry) and thermal desorption spectroscopy detected by quadrupole mass spectroscopy ( $\mathrm{He}$ flow of $150 \mathrm{ml} / \mathrm{min}$ and heating rate of $5 \mathrm{~K} / \mathrm{min}$ ). All of the samples were always handled in a glove box filled with purified $\mathrm{Ar} / \mathrm{He}$ (dew point below $183 \mathrm{~K}$ ) gas to avoid (hydro-)oxidation.

\section{Results and discussion}

\subsection{Syntheses of $M L i_{m-n}\left(B H_{4}\right)_{m}$}

Fig. 2 shows the powder X-ray diffraction profiles of the samples after mechanical milling of (a) $\mathrm{ZnCl}_{2}+m \mathrm{LiBH}_{4}$ ( $m=2$ and 3), (b) $\mathrm{AlCl}_{3}+m \mathrm{LiBH}_{4}\left(m=3\right.$ and 4) and (c) $\mathrm{ZrCl}_{4}+m \mathrm{LiBH}_{4}$ $(m=4-6)$. The profiles of starting materials $\mathrm{ZnCl}_{2}, \mathrm{AlCl}_{3}, \mathrm{ZrCl}_{4}$

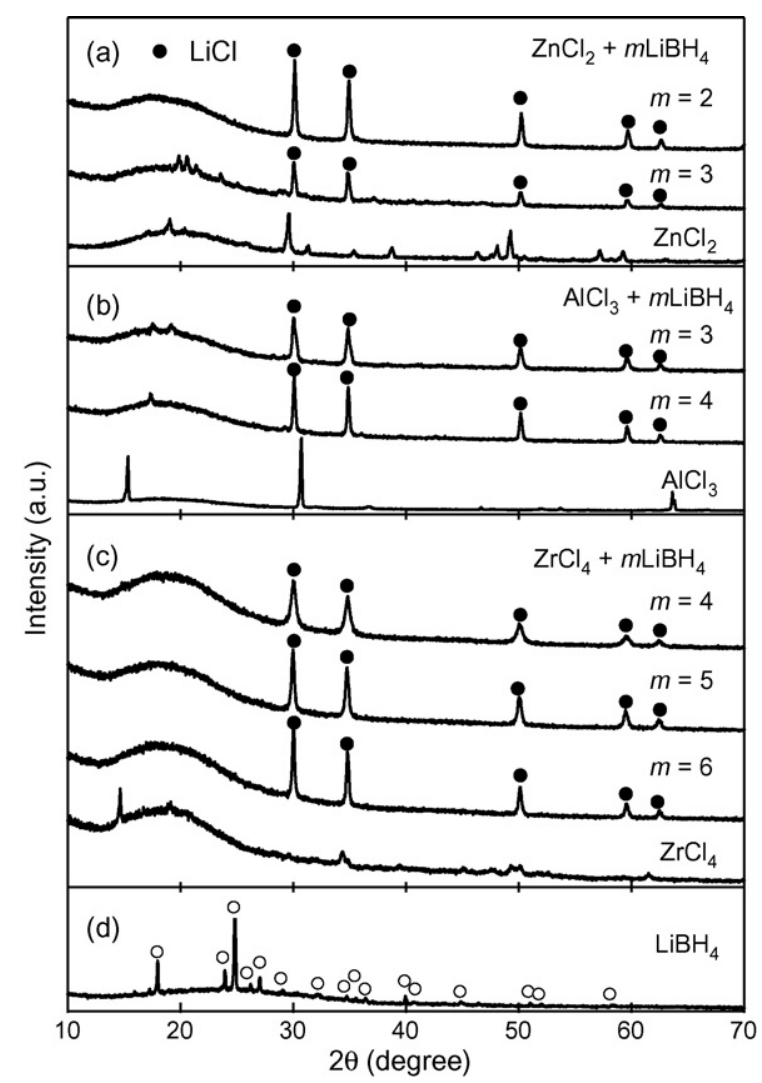

Fig. 2. Powder $\mathrm{X}$-ray diffraction profiles of the samples after mechanical milling of (a) $\mathrm{ZnCl}_{2}+m \mathrm{LiBH}_{4}(m=2,3)$, (b) $\mathrm{AlCl}_{3}+m \mathrm{LiBH}_{4}(m=3,4)$, (c) $\mathrm{ZrCl}_{4}+m \mathrm{LiBH}_{4}(m=4-6)$ and (d) the purchased $\mathrm{LiBH}_{4}$. The profiles of starting materials $\mathrm{ZnCl}_{2}, \mathrm{AlCl}_{3}$ and $\mathrm{ZrCl}_{4}$ are also shown for references. 


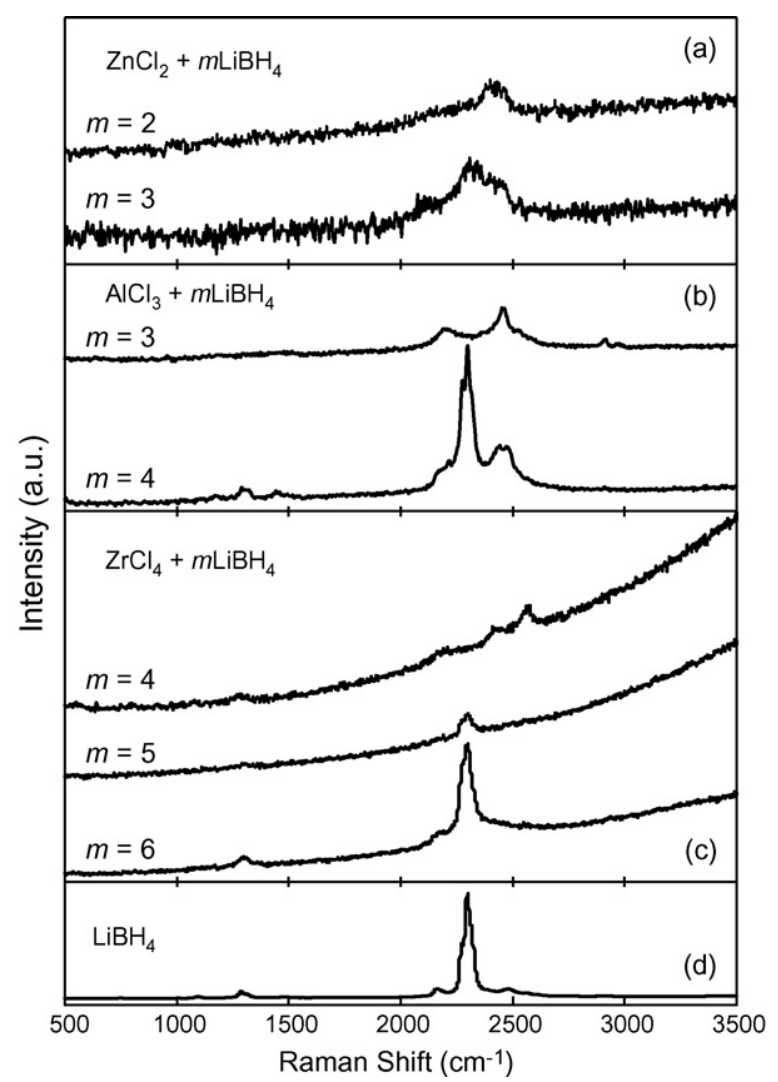

Fig. 3. Raman spectra of the samples after mechanical milling of (a) $\mathrm{ZnCl}_{2}+m \mathrm{LiBH}_{4}(m=2,3)$, (b) $\mathrm{AlCl}_{3}+m \mathrm{LiBH}_{4}(m=3,4)$, (c) $\mathrm{ZrCl}_{4}+m \mathrm{LiBH}_{4}$ $(m=4-6)$ and (d) the purchased $\mathrm{LiBH}_{4}$.

and $\mathrm{LiBH}_{4}$ are also shown for references. The broad diffraction peaks at around $20^{\circ}$ in all the profiles, result from the diffraction of tape covered samples to avoid exposing to air. $\mathrm{LiCl}$, one of the products of Eq. (1), is identified in all the diffraction profiles for the samples after mechanical milling. Furthermore, no diffraction peaks of the starting materials of $\mathrm{MCl}_{n}$ and $\mathrm{LiBH}_{4}$ are observed. Thus, the $\mathrm{X}$-ray diffraction results suggest the progression of reaction of Eq. (1), i.e. the possible formation of $\mathrm{MLi}_{m-n}\left(\mathrm{BH}_{4}\right)_{m}$ and $\mathrm{LiCl}$.

There is no traces of $\mathrm{MLi}_{m-n}\left(\mathrm{BH}_{4}\right)_{m}$ in the X-ray diffraction profiles, which is due to the absence of any long range ordering in the structure, similar to other $\mathrm{M}\left(\mathrm{BH}_{4}\right)_{n}$ synthesized by mechanical milling [16,17]. Therefore, Raman spectra were examined to obtain information on the $\mathrm{B}-\mathrm{H}$ bonding to confirm the existence of $\mathrm{MLi}_{m-n}\left(\mathrm{BH}_{4}\right)_{m}$ in the samples prepared by mechanical milling. The Raman spectra of the samples after mechanical milling are shown in Fig. 3. The spectrum of $\mathrm{LiBH}_{4}$ is also shown as a reference, where the $\mathrm{B}-\mathrm{H}$ stretching $\left(v_{1}\right)$ and bending ( $v_{1}$ and also $v_{2}^{\prime}$ ) modes in the $\left[\mathrm{BH}_{4}\right]^{-}$complex anion are observed at around 2300 and $1300 \mathrm{~cm}^{-1}$, respectively. Since $\mathrm{ZnLi}_{m-2}\left(\mathrm{BH}_{4}\right)_{m}(m=2$ and 3) is easily scorched by laser irradiation for Raman spectroscopy, only a small and weak peak at about 2400 or $2300 \mathrm{~cm}^{-1}$ is observed, respectively, which are expected to correspond to the stretching modes of the $\mathrm{B}-\mathrm{H}$ bonding. There are two or three stretching modes at around $2200-2580 \mathrm{~cm}^{-1}$ in the Raman spectra of the synthesized
$\mathrm{Al}\left(\mathrm{BH}_{4}\right)_{3}$ and $\mathrm{Zr}\left(\mathrm{BH}_{4}\right)_{4}$, as shown in Fig. 3(b and c), respectively $[25,26]$. On the other hand, the similar vibration modes in the $\left[\mathrm{BH}_{4}\right]^{-}$complex anion to that of $\mathrm{LiBH}_{4}$ are observed in the Raman spectra of the samples with double-cation, i.e. $\mathrm{ZnLi}\left(\mathrm{BH}_{4}\right)_{3}, \mathrm{AlLi}\left(\mathrm{BH}_{4}\right)_{4}, \mathrm{ZrLi}\left(\mathrm{BH}_{4}\right)_{5}$ and $\mathrm{ZrLi}_{2}\left(\mathrm{BH}_{4}\right)_{6}$. The varieties in the Raman spectra depending on the sample compositions, which are expected to be due to the change of the condition surrounding the $\left[\mathrm{BH}_{4}\right]^{-}$anion, indirectly indicate the progression of Eq. (1).

\subsection{Thermal desorption properties of $M \mathrm{Li}_{m-n}\left(\mathrm{BH}_{4}\right)_{m}$}

Fig. 4 shows the hydrogen desorption profiles of the mixture of $\mathrm{MCl}_{n}+m \mathrm{LiBH}_{4}$ after mechanical milling, detected by quadrupole mass spectroscopy. Though the samples synthesized by mechanical milling is mixtures of $\mathrm{MLi}_{m-n}\left(\mathrm{BH}_{4}\right)_{m}$ and $\mathrm{LiCl}$, the thermal desorption profiles originate only from $\mathrm{MLi}_{m-n}\left(\mathrm{BH}_{4}\right)_{m}$, because $\mathrm{LiCl}$ decomposes at the temperature higher than $878 \mathrm{~K}$. The result of $\mathrm{LiBH}_{4}$ is also shown as a reference. Both $\mathrm{Zn}\left(\mathrm{BH}_{4}\right)_{2}$ and $\mathrm{Al}\left(\mathrm{BH}_{4}\right)_{3}$ have lower $T_{\mathrm{d}}$ as shown in Fig. 4(a and b), i.e. 393 and $334 \mathrm{~K}$, respectively; but impurity gases of diborane, were released along with the desorption of hydrogen (not shown) [18,19]. On the other hand, the thermal desorption profiles of the samples with the compositions of $\mathrm{ZnLi}\left(\mathrm{BH}_{4}\right)_{3}$ and $\mathrm{AlLi}\left(\mathrm{BH}_{4}\right)_{4}$ indicate that both

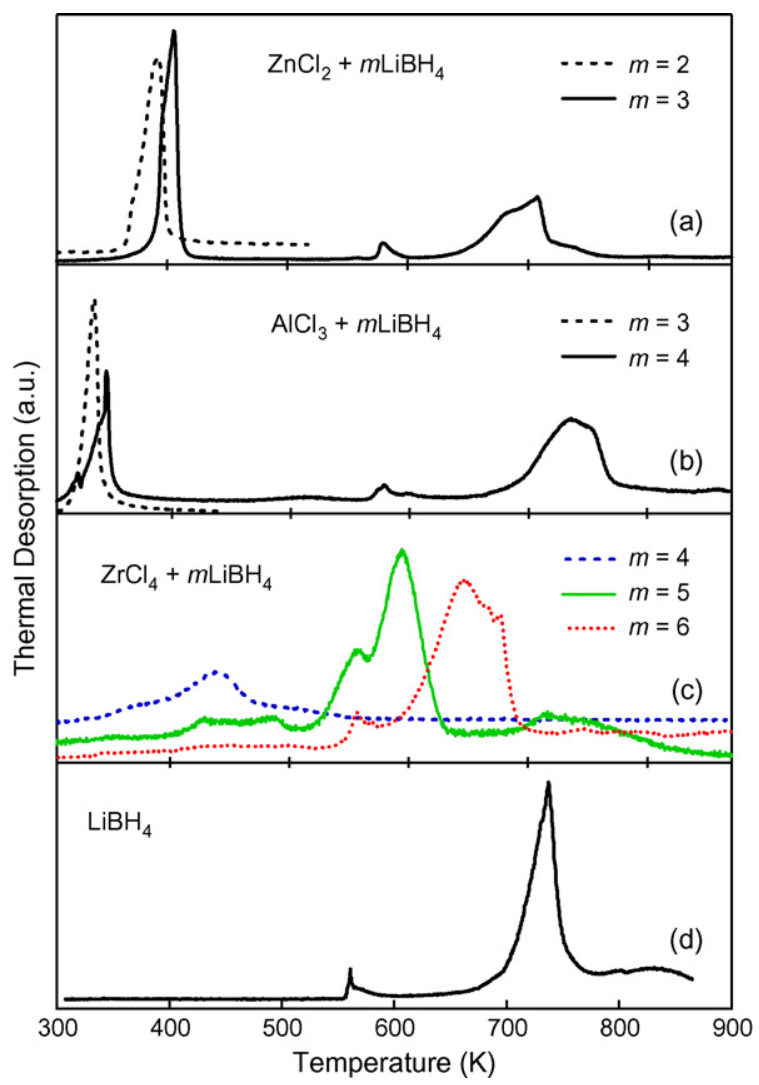

Fig. 4. Thermal desorption profiles of the samples after mechanical milling of (a) $\mathrm{ZnCl}_{2}+m \mathrm{LiBH}_{4} \quad(m=2,3), \quad$ (b) $\mathrm{AlCl}_{3}+m \mathrm{LiBH}_{4} \quad(m=3,4)$, (c) $\mathrm{ZrCl}_{4}+m \mathrm{LiBH}_{4}(m=4-6)$ and (d) the purchased $\mathrm{LiBH}_{4}$ detected by quadrupole mass spectroscopy. $T_{\mathrm{d}}$ of $\mathrm{ZrCl}_{4}+m \mathrm{LiBH}_{4}(m=4-6)$ after mechanical milling is summarized in Fig. 1 with open circles. 
of them disproportionate into $\mathrm{Zn}\left(\mathrm{BH}_{4}\right)_{2^{-}}$(or $\left.\left.\mathrm{Al}\left(\mathrm{BH}_{4}\right)_{3}\right)^{-}\right)$and $\mathrm{LiBH}_{4}$-based phases during heating process, respectively. The peaks below $400 \mathrm{~K}$ for $\mathrm{ZnLi}_{m-4}\left(\mathrm{BH}_{4}\right)_{m}$ and $\mathrm{AlLi}_{m-4}\left(\mathrm{BH}_{4}\right)_{m}$ shift slightly to higher temperature side about $10 \mathrm{~K}$ with the increasing value of $m$, probably originating from the partial combination effect of $\mathrm{Zn}$ or $\mathrm{Al}$ with $\mathrm{Li}$, respectively.

However, it is worth emphasizing that hydrogen desorption profiles of $\mathrm{ZrLi}\left(\mathrm{BH}_{4}\right)_{5}$ and $\mathrm{ZrLi}_{2}\left(\mathrm{BH}_{4}\right)_{6}$ do not show obvious disproportionation reaction into $\mathrm{Zr}\left(\mathrm{BH}_{4}\right)_{4}$ - and $\mathrm{LiBH}_{4}$-based phases upon heating, although some additional reactions with small peaks are detected. Only hydrogen was detected in the thermal desorption measurement of $\mathrm{ZrLi}_{m-4}\left(\mathrm{BH}_{4}\right)_{m}$. Moreover, $T_{\mathrm{d}}$ for $\mathrm{ZrLi}_{m-4}\left(\mathrm{BH}_{4}\right)_{m}$, i.e. $440 \mathrm{~K}(m=4), 595 \mathrm{~K}(m=5)$ and $650 \mathrm{~K}$ $(m=6)$, shifts gradually to higher temperature with increasing composition ratio of $\mathrm{Li} / \mathrm{Zr}$ and continuously approaches to $740 \mathrm{~K}$ which is $T_{\mathrm{d}}$ for $\mathrm{LiBH}_{4}$.

The relationship between $T_{\mathrm{d}}$ and the averaged value of $\chi_{\mathrm{P}}$ of $\mathrm{ZrLi}_{m-4}$ is expressed in Fig. 1. Here, the averaged value of $\chi_{\mathrm{P}}$ for $\mathrm{ZrLi}_{m-4}$ depending on $m$ is simply calculated as follows:

$\chi_{\mathrm{P}}=\frac{1.4+1.0(m-4)}{1+(m-4)}$.

Apparently, $T_{\mathrm{d}}$ of $\mathrm{ZrLi}_{m-4}\left(\mathrm{BH}_{4}\right)_{m}$, namely $\mathrm{MM}^{\prime}\left(\mathrm{BH}_{4}\right)_{n}$ with double-cation, is closely related to the averaged $\chi_{\mathrm{P}}$ as what have been observed in the $\mathrm{M}\left(\mathrm{BH}_{4}\right)_{n}$ with a single cation [16]. This experimental feature highly suggests that the hydrogen desorption temperature of metal borohydrides can be precisely adjusted by the appropriate combination of cations. The criteria for the selection of appropriate cations which can effectively and precisely adjust hydrogen desorption temperature are expected to be clarified in near future.

Some additional reactions with small peaks in Fig. 4 are possibly resulted from small amounts of residual $\mathrm{LiBH}_{4}$ as the starting material and Zr-rich borohydrides in the milled samples. The origin of these peaks cannot be well clarified due to the absence of diffraction peaks of other phases except for $\mathrm{LiCl}$, as shown in Fig. 2. New synthesis processes of well-crystallized $\mathrm{ZrLi}_{n-4}\left(\mathrm{BH}_{4}\right)_{n}$ are now being developed, which seems to be indispensable for the further study.

\section{Summary}

A series of double-cation borohydrides $\mathrm{MLi}_{m-n}\left(\mathrm{BH}_{4}\right)_{m}$ $(\mathrm{M}=\mathrm{Zn}, n=2 ; \mathrm{M}=\mathrm{Al}, n=3 ; \mathrm{M}=\mathrm{Zr}, n=4 ; n \leq m)$ were expected to be synthesized by mechanical milling of $\mathrm{MCl}_{n}$ and $\mathrm{mLiBH}_{4}$. Their thermodynamical stabilities were examined by quadrupole mass spectroscopy. Thermal desorption measurement results indicate that the samples with the compositions of $\mathrm{ZnLi}\left(\mathrm{BH}_{4}\right)_{3}$ and $\mathrm{AlLi}\left(\mathrm{BH}_{4}\right)_{4}$ disproportionate into $\mathrm{Zn}\left(\mathrm{BH}_{4}\right)_{2}-$ (or $\left.\left.\mathrm{Al}\left(\mathrm{BH}_{4}\right)_{3}\right)^{-}\right)$and $\mathrm{LiBH}_{4}$-based phases upon heating, respectively. However, no disproportionation reaction into $\mathrm{Zr}\left(\mathrm{BH}_{4}\right)_{4}$ - and $\mathrm{LiBH}_{4}$-based phases is confirmed in the case of $\mathrm{ZrLi}_{m-4}\left(\mathrm{BH}_{4}\right)_{m}$. The hydrogen desorption temperature $T_{\mathrm{d}}$ of $\mathrm{ZrLi}_{m-4}\left(\mathrm{BH}_{4}\right)_{m}$ increases from $440 \mathrm{~K}(m=4)$ to $650 \mathrm{~K}(m=6)$ and continuously approaches to $740 \mathrm{~K}\left(T_{\mathrm{d}}\right.$ of $\left.\mathrm{LiBH}_{4}\right)$. That is, $T_{\mathrm{d}}$ of $\mathrm{ZrLi}_{m-4}\left(\mathrm{BH}_{4}\right)_{m}$, namely $\mathrm{MM}^{\prime}\left(\mathrm{BH}_{4}\right)_{n}$ with double-cation is closely related to the averaged $\chi_{\mathrm{P}}$ as what have been observed in the $\mathrm{M}\left(\mathrm{BH}_{4}\right)_{n}$ with a single cation. Consequently, the abovementioned results indicate that the appropriate combination of cations is an effective method to adjust the thermodynamical stability of metal borohydrides, similar to the conventional "alloying" method for hydrogen storage alloys.

\section{Acknowledgements}

This study was partially supported by the New Energy and Industrial Technology Development Organization (NEDO), International Joint Research under the "Development for Safe Utilization and Infrastructure of hydrogen" Project (2005-2007) and the Grants-in-Aid of Japan Society for the Promotion of Science (JSPS).

\section{References}

[1] A. Züttel, S. Rentsch, P. Fisher, P. Wenger, P. Sudan, Ph. Mauron, Ch. Emmenegger, J. Alloys Compd. 356-357 (2003) 515-520.

[2] A. Züttel, P. Wenger, P. Sudan, Ph. Mauron, S. Orimo, Mater. Sci. Eng. B 108 (2004) 9-18.

[3] S. Orimo, Y. Nakamori, A. Züttel, Mater. Sci. Eng. B 108 (2004) 51-53.

[4] H. Hagemann, S. Gomes, G. Renaudin, K. Yvon, J. Alloys Compd. 363 (2004) 129-132.

[5] K. Miwa, N. Ohba, S. Towata, Y. Nakamori, S. Orimo, Phys. Rev. B 69 (2004) 245120

[6] G. Renaudin, S. Gomes, H. Hagemann, L. Keller, K. Yvon, J. Alloys Compd. 375 (2004) 98-106.

[7] P. Vajeeston, P. Ravindran, A. Kjekshus, H. Fjellvåg, J. Alloys Compd. 387 (2005) 97-104

[8] K. Miwa, N. Ohba, S. Towata, Y. Nakamori, S. Orimo, J. Alloys Compd. 404-406 (2005) 140-143.

[9] M. Yoshino, K. Komiya, Y. Takahashi, Y. Shinzato, H. Yukawa, M. Morinaga, J. Alloys Compd. 404-406 (2005) 185-190.

[10] S. Orimo, Y. Nakamori, G. Kitahara, K. Miwa, N. Ohba, S. Towata, A. Züttel, J. Alloys Compd. 404-406 (2005) 427-430.

[11] S. Orimo, Y. Nakamori, N. Ohba, K. Miwa, M. Aoki, S. Towata, A. Züttel, Appl. Phys. Lett. 87 (2005) 021920.

[12] J.K. Kang, S.Y. Kim, Y.S. Han, R.P. Muller, W.A. Goddard III, Appl. Phys. Lett. 87 (2005) 111904

[13] R.S. Kumar, A.L. Cornelius, Appl. Phys. Lett. 87 (2005) 261916.

[14] Y. Nakamori, S. Orimo, T. Tsutaoka, Appl. Phys. Lett. 88 (2006) 112104.

[15] T. Matsunaga, F. Buchter, K. Miwa, S. Towata, S. Orimo, A. Züttel, Proceedings of the E-MRS 2006 Spring Meeting, Nice, France, May 29-June $2,2006$.

[16] Y. Nakamori, K. Miwa, A. Ninomiya, H.-W. Li, N. Ohba, S. Towata, A. Züttel, S. Orimo, Phys. Rev. B 74 (2006) 045126.

[17] Y. Nakamori, H.-W. Li, K. Miwa, S. Towata, S. Orimo, Mater. Trans. 47 (2006) 1898-1901.

[18] E. Jeon, Y.W. Cho, J. Alloys Compd. 422 (2006) 273-275.

[19] Y. Nakamori, H.-W. Li, M. Aoki, K. Miwa, S. Towata, S. Orimo, J. Alloys Compd., in press.

[20] H.-W. Li et al., Collected abstracts of the 2006. Autumn Meeting of the Japan Institute of metals (Sept. 16-18, 2006), p. 198.

[21] T.B. Flanagan, W.A. Oates, in: L. Schlapbach (Ed.), Hydrogen in Intermetallic Compounds I, Springer-Verlag, Berlin, 1988, pp. 49-85.

[22] Y. Fukai, The Metal-Hydrogen System, Basic Bulk Properties, SpringerVerlag, Berlin, Heidelberg, 1993, pp. 1-70.

[23] V.M. Ehemann, H. Nöth, Z. Anorg. Allg. Chem. 386 (1971) 87-101.

[24] D.R. Lide (Ed.), CRC Handbook of Chemistry and Physics, 83rd ed., CRC Press, 2002-2003, pp. 5-5-5-25.

[25] N. Davies, P.H. Bird, M.G.H. Wallbridge, J. Chem. Soc. A Inorg. Phys. Theor. (1968) 2269-2272.

[26] N. Davies, M.G.H. Wallbridge, B.E. Smith, B.D. James, J. Chem. Soc. Dalton Trans. (1973) 162-165. 